\title{
Measurement of GVA in Indian Banks: Some Preliminary Results
}

N.K.Unnikrishnan and Balwant Singh

Quantitative Approaches to Public Policy Conference in Honour of Professor T. Krishna Kumar

Held in conjunction with the

Fourth Annual International Conference on Public Policy and Management Indian Institute of Management Bangalore (IIMB)

9-12 August 2009

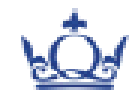

School of Business and Management Queen Mary, University of London London, United Kingdom

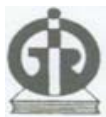

Indira Gandhi Institute of Development Research Mumbai, India

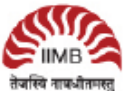

Centre for Public Policy Indian Institute of Management Bangalore, India 


\title{
Measure ment of GVA in Indian Banks: Some Preliminary Results
}

\author{
by
}

\section{N.K.Unnik rishnan and Balwant Singh ${ }^{1}$ \\ Department of Statistics \& Information Manage ment Reserve Bank of India}

ABSTRACT: Measurement of Gross Value Added (GVA) in banking sector is still a debatable and unresolved issue. Current proposals for measuring GVA are the following: (a) SNA93's FISIM approach, (b) user cost of money approach promoted by a set of researchers led by Fixler; and, (c) margin industry approach suggested by Triplett and Bosworth. Each of the method has merits and lacunae, especially for measurement of GVA for a developing country like India. In this background, the paper examines relevance of these approaches vis-à-vis output of banks as perceived in the theoretical banking models.

\section{Introduction}

Banking is significant in many ways in the economy. It is important in terms of its intermediation function - channeling savings from net savers to net borrowers. It is important in terms of the finance flow of accounts, its share of total production in the economy and trade. The banks' importance in terms of moving funds from lenders to borrowers and their role in creation of money makes them carriers and transmitters of monetary policy signals (Collins and Sciadas, 1993).

In the Indian environment, where banks are a major source of finance, the contribution of banks towards promoting and enhancing growth becomes much more significant. The emphasis of financial inclusion reflects the importance being accorded to the role of banking in expanding horizon of economic activities across the country and across various population groups.

\footnotetext{
${ }^{1}$ Views expressed in this paper are purely personal and not of the institution with which authors are associated.
} 
In view of the significant role of banks in accelerating economic growth and, their increasing importance in domestic and international trade, it is vital to measure the output of banks appropriately. As impact of technological developments is reflected much more on the banking sector compared to any other sector of the economy, the issue of banks' output measurement has further gained importance.

The satisfactory measurement of banking output has, however, eluded statistical agencies since the inception of national accounting. In this background, the present paper attempts to provide a critical review of the existing methodologies of measuring banks output with certain theoretical and empirical evidences. The paper is divided into seven sections. At the outset in Section 2, we provide difficulties faced in national accounts with regard to interest rates. Section 3 provides a brief description on the basic functions of the banks followed by the SNA dilemma regarding banks output and literature thereof with specific reference to India. A critical evaluation of existing methods of estimating banks' output has been given in Section 4. In Section 5 we discuss certain inadequacies of the exiting methodologies and highlight the 'missing component' in the measurement of banks' output. Section 6 provides quantitative measure obtained using the exiting methodologies in order to conceptually clarify the issues further. Broad conclusions of the study are provided in Section 7. References cited in the study are given at the end.

\section{The SNA dilemma of meas ure ment of banks' output}

The dilemma of the measurement of banking output is the treatment of interest in the national accounts. The Gross Domestic Product (GDP) originating in an industry can be equivalently arrived at from the income or the value-added approaches. According to the income approach, GDP is equivalent to the sum of labour income and property inco me accruing from the industry's production. According to the value-added approach, GDP is equal to revenues accruing from production less the values of purchases of intermediate inputs. Thus, according to the above convention, net interest paid is a part of the GDP originating in the paying industry. Thus, in brief interest payments have been seen a 
factor payments for the borrower and as transfer income for the lender. This is the beginning of the problem. Accounting consistency in SNA structure requires that the same treatment be carried out in the financial sector, i.e. banks, also.

As elucidated in Sciadas (1994), this issue can be illustrated as below:

Let total revenue $(R)$ and total expenses $(E)$ for the banking industry be given as equation (1) and equation (2) respectively:

$R=I_{l}+F$

$E=W+M+I_{d}+\pi$

where $I_{l}$ and $I_{d}$ denote interest receipts from loans and interest payments to depositors respectively, $F$ is service charges, $W$ is labour costs, $M$ intermediate inputs and $\pi$ is profits. Profits are derived residually and thus

$R=E$

In the usual conventional way of SNA the GDP originating in the industry ( $Y$ ) will be given by:

$Y=W+\pi+\left(I_{d}-I_{l}\right)$

or equivalently

$Y=F-M$

In case of banks $I_{d}-I_{l}$ is negative and, thus GDP as given by equation (4) or (5) will be unrealistically low and possibly negative. In general, the GDP will be negative if the value of explicit service charges falls short of the value of intermediate inputs $(F<M)$ or if the absolute value of interest paid by the banks exceeds the sum of labour costs and 
profits. The operating surplus will be negative if explicit services charges are less than the value of intermediate inputs and labour costs.

To avoid this problem of excessively low measured output, a value for value of banking services, equal to the net interest received by banks, is imputed. This is based on the logic that banks and depositors short-circuit the market process and barter "free" services for foregone interest. In other words, lower interest is paid on deposits than would have been paid if depositors were required to pay fully and explicitly for all the services they purchase.

Incorporating the imputation into the basic approach we get:

$R=I_{l}+F+T$

$E=W+M+I_{d}+T+\pi$

where $T$ reflects the imputed cost of providing services in kind on the expenditure side, and the ir payments of equal value on the revenue side and

$T=I_{l}-I_{d}$

Then, taking (8) into account, GDP originating in the ind ustry will be given by:

$Y=W+\pi$

or

$Y=\left(I_{l}-I_{d}\right)+F-M$

Use of this imputation method is meant to take care of the problem of negative or unrealistically low banking output. However, this method has been criticized on many counts, some of which enumerated below briefly. 
One of the criticisms of the imputation approach is that it results into overestimation of the aggregate output. This is so because all interest paid, economy-wide has already been counted as the contribution to overall output by all other non-financial industries - which of course is equal to interest received by the banks. This new "inconvenience" of double counting that stems from carrying out of the imputation was, however, addressed by the recommendation to create a fictitious industry within the financial sector, which would be allotted the same but negative output.

Another criticism of the imputation method has been that it proposed to allocate entirely to the deposit sector. Financial services offered by the banks to borrowers, a most fundamental aspect of banking, were completely ignored.

Following the imputation method, the allocation of the banks output to the various parts of the accounts, such as consumption expenditure and exports on the expenditure side, and intermediate consumption in the input-output tables has been problematic and also distorted. In order to resolve these issues, different countries adopted different practices which hindered international comparability of banks output. As a result of these limitations comparability of productivity trends in banks across countries became difficult. These limitations of the imputations methodology paved a way for further research into the definitional and measurement issues of banks output covered subsequently in this paper. Initially, in the next section we briefly recapitulate basic functions of banks in order to obtain broader view on the various issues relating to banks' output.

Despite these criticisms, the simple model presented here, especially of equation (10), is the basis for computation of GVA of commercial banks currently followed by CSO; Section 6.1 discusses this in more detail. 


\section{Basic functions of banks}

Broadly, banks function in the same way as other firms, employing factors of production, transform them to produce output, have intermediate consumption and generate value added. The distinction between the (industrial) firms and banks being that in case of banks money not only serves as the accounting unit but also constitute the traded unit. There are various views regarding the basic functions of banks on how those could be categorized.

As per the most prominent view the most basic function of a bank is to channel deposits from household sector and lend these deposits to households, companies and the government. The process of channeling deposits and providing them as funds to the productive sectors of the economy is very crucial in the modern world. Banks perform one of the basic functions of modern economy: it converts highly liquid liabilities (deposits) into most illiquid assets (credit). In order to appreciate this point, consider the balance sheet of banks. Major portion of the assets of a bank's balance sheet comes from lending activity. Major portion of the liability side of the balance sheet of a bank is deposits. As argued by Douglas Diamond and Raghuram Rajan in a series of papers, lending operations of banks results in illiquid assets: loans provided to a factory, for building roads, or for buying consumer durables are highly illiquid in the sense that these amounts are difficult to recover before the time contracted by the bank and the borrower. However, money being lent is generated through deposits. These deposit liabilities are presumed to be highly liquid, in the sense that depositors can demand their full principal back at any moment. This is true for savings bank accounts. What is not so well recognized is the fact that this is equally true for term deposits. If a term depositor is ready to sacrifice the interest portion, he can get his principal back at any time. Thus, major portion of liabilities of banks are highly liquid. Thus, banks need to manage a balance sheet which is inherently unstable. The intermediation process involves quantity transformation of financial capital - viz., savers save in different quantities than borrowers want to borrow; time transformation of financial capital - viz., the time horizon 
of savers and borrowers is likely to differ and geographical transformation of financial capital - viz., deposits mobilized at certain places are utilized at other places.

The genesis of the intermediation services performed by banks could perhaps be traced to the existence of asymmetric information and adverse selection. For example, in case depositors want to directly lend to borrowers, they (depositors) are unlikely to have full information on credit-worthiness of borrowers. By way of directly lending to borrowers, depositors may face the risk of default. Depositors also may face a problem of adverse selection in case they (depositors) want to lend directly to borrowers. A borrower may wish to overstate his credit-worthiness to potential lender (a depositor) in order to make himself look like a low-credit borrower. And if a lender raises interest rate in order to be compensated for higher credit risk associated with borrowers, who misrepresent their credit worthiness, borrowers most likely to drop out are the low-credit borrowers who may either have better credit alternatives or be willing be simply unwilling to borrow at the higher interest rate. Consequently, the lender (depositor) is left with high-credit-risk borrower causing a problem of adverse selection. In fact, bank is likely to deal with such issues of adverse selection by way of performing some type of brokerage functions of credit analysis to sort out borrowers of different credit risks. That is, in such cases bank specializes in credit analysis or develops the skills to develop to process various type of information. This allows the bank to intermediate between borrowers and lenders and minimize adverse selection problem and charge a premium from the depositors by way of providing him (depositor) less amount of interest. Similar to depositors, banks provide services to borrowers by way of pooling resources from (small) depositors and making available to large borrowers. In case borrowers would have to mobilise such financial resources on their own it would have accounted them a substantial cost. Similarly, banks are able to able to shift resources from places surplus in nature to those facing scarcity. It is the se services which banks provide to borrowers and charge higher rate of interest than those charged from depositors. These discussions reflect that banks output depends both on depositors and borrowers and should be based on the level of deposits and credit. These discussions also reflect that banks' output depends on the margin of interest rate 
banks pay less to depositors and margin of interest rate they (banks) charge higher from borrowers.

Thus, there appears to be very diverse opinion regarding basic functions of banks. Naturally, views on estimation of output of banks are also equally diverse; synoptic views of some of these have been provided in the next section.

\section{Methods of estimation of banks output: Review of existing methods}

Among different methodologies towards estimation of GVA of banks, we discuss three methods, viz., user cost of money, Financial Intermediary Services Indirectly Measured (FISIM) and margin industry perspective. We provide a brief on these methodologies as follows.

\subsection{User cost of money}

Hancock (1985) developed a theory of production for the financial firm in which the input and output status of individual financial products can be determined empirically. This approach is based on the user cost of money as developed by Donovan (1978) and Barnett (1980). The user cost of each asset is calculated as a difference between bank's opportunity cost of capital and its holding revenue. The user cost of each liability is calculated as difference between its holding cost and bank's opportunity cost of money. When a positive user cost is attached to an asset (because it's holding revenue is insufficient to cover the opportunity cost of capital), this will contribute to the financial firm's costs and such an asset is therefore classified as an input. When the opposite is true, the asset adds to the firm's revenue and is therefore classified as an output. The same is true of liabilities, which can also be classified endogenously as either inputs or outputs depending on the sign of associated user cost. For example, a deposit whose holding cost (interest due plus the cost of services not explicitly charged) falls short of the opportunity cost of money will add to revenue and thus be classified as an output. 
Ignoring all non-essential components, such as reserve requirements, loan loss provisions, and other regulatory and non-regulatory charges, user cost of an asset has three essential components: interest rate received on loans $\left(r_{a}\right)$, explicit service charges received $\left(s_{a}\right)$ and the opportunity cost $(\rho)$, with all the three charged for per unit of currency. These three components come together in the user cost approach as follows:

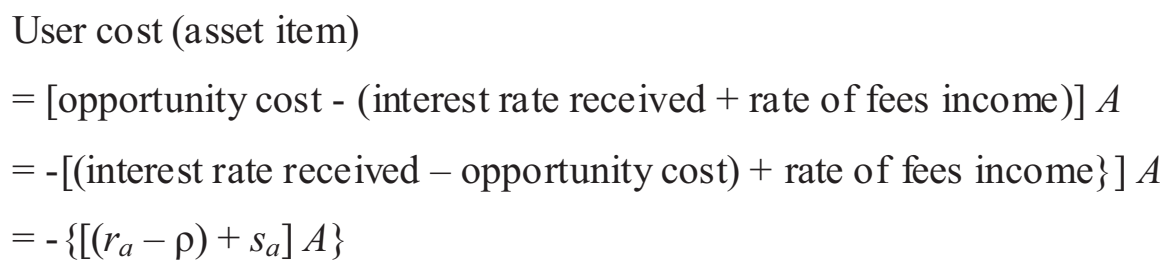

where $A$ is the average outstanding asset item during the year.

Similarly, for a liability item, user cost can be defined as follows. Here again, ignoring non-essential components (deposit insurance, for instance), user cost of a liability has three components: interest rate payable $\left(r_{l}\right)$, explicit service charges received $\left(s_{l}\right)$ and the opportunity cost $(\rho)$, with all the three charged for per unit of currency. These three components come together in the user approach as follows:

User cost (liability item)

$=[$ opportunity cost $-($ interest rate received + rate of fees income $)] L$

$=-[($ interest rate received - opportunity $\cos t)+$ rate of fees income $\}] L$

$=-\left\{\left[\left(\rho-r_{l}\right)+s_{l}\right] L\right\}$

where $L$ is the average outstanding liability item during the year.

Equations (11) and (12) will be used in formulating FISIM approach in the next subsection.

These equations also provide a methodology to classify a liability or an asset, either as an input or as an output, depending on revenue it generates for the firm. The user cost 
approach considers all financial services as output but assumes that financial products (like deposits and advances, etc.) can play the role of "financial output" or "financial input" in the financial operations. A financial product may also change its financial input / output status over time. The deciding factor of the financial input-output status of a product at any time is the user cost of the product at that time. As can be seen from the equations (11) and (12), user cost of a product may be positive or negative. The determining factor is the relationship between the holding revenue or holding cost and the opportunity cost of money. The sign of product's user cost determines its input / output status. If the user cost is negative, then the product is a financial output because the user cost is negative of the contribution to the revenue associated with the product. If the user cost is positive, then the product is a financial input. Thus, the user cost approach allows a financial product to change its financial input / output status over time.

\section{User cost approach - criticism}

An important aspect of user cost approach is the need to discover some measure of opportunity cost of money $\rho$. In the literature, various measures of $\rho$ have been proposed. The choice of an appropriate opportunity cost is important, as national accountants are unlikely to be conformable with a situation wherein input / output nature of an item changes very often. Empirical research favours an average rate between all major assets and liabilities. In the Indian context, Barman and Samanta (2004) provides a detailed discussion on this issue.

There continues to be an active debate on the choice of $\rho$, which also leads to a set of criticism against user cost approach. Some of these debates are given below.

1) There are no standard ways of selecting an opportunity cost, but Fixler recommends government bond rate. However, in developing countries such as India, ordinary depositors rarely invest in government bonds, thus making government bond rate as an inappropriate "opportunity cost". 
2) Consider a case wherein Bank $\mathrm{A}$ charges higher interest rate for a product vis-à-vis Bank B, ceterus paribus. According to user cost approach, Bank A contributes more towards banking sector output, which seems incorrect because Bank B charges lower rate because it may be able to make more efficient use of depositors' money resulting in lower spread.

3) Deposit holders contribute "positively" if they receive interest rate lower than $\rho$. However, if deposit holders receive higher interest than $\rho$, they do negative service to the bank; this is not very convincing.

4) Banks charge differently from different borrowers, depending on the risk profile. According to user cost approach, bank provides more service to a borrower with higher risk profile. This differentiation may not be appropriate from a national account perspective. This point towards the need for a "risk-adjusted" user cost approach, as argued by Wang, Basu and Fernald (2004).

5) Barman and Samanta (2004) observes that some of the commonly available rates in India, such as call rate and treasury rates, if taken as opportunity cost, results in frequent changes in the nature of input / output status of major banking aggregates.

\subsection{Financial Intermediary Services Indirectly Measured (FISIM)}

Broadly, FISIM may be viewed as special case of user cost method, with a few modifications.

In order to overcome the issue of SNA dilemma in general and underestimation of output from banking sector especially for countries which are heavily depending on income from international banking as a major source of income (Luxemburg, Switzerland, to name two such countries), SNA93 advocated the use of FISIM. FISIM approach is very similar to that of the user cost approach described in Section 4.1, which anchors on a "reference rate" (opportunity cost, the term used in user cost approach). 
As per SNA93, FISIM is defined as "the total property income receivable by financial intermediation minus their total interest payable, excluding the value of any property income receivable from the investment of their own funds, as such income does not arise from financial intermediation." The own fund aspect in the definition is generally ignored, due to difficulties in its implementation (OECD, 1998). SNA and OECD documents prefer the term "reference rate" instead of "opportunity cost" which is more popular in the context of user cost approach.

Our implementation of FISIM is now illustrated for an asset item and a liability item as below.

FISIM on loans

$=$ Average Balance on loans * (Effective rate on loans - Reference Rate)

$=\left[\left(r_{a}-\rho\right)\right] A$.

FISIM on deposits

$=$ Average balance on deposits * (Reference Rate - Effective Rate on Deposits)

$=\left[\left(\rho-r_{l}\right)\right] L$.

Equations (13) and (14) may be derived from equations (11) and (12), by ignoring negative signs and explicit service charges.

In Indian banking data as published in "Statistical Tables Relating to Banks in India", direct service charges are not available separately for each asset and liability item. Instead, a single total data item is published, called "other income", which represents all explicitly charged income components of commercial banks. Thus, it may be more convenient to define GVA from banks on aggregate basis as follows.

GVA from banks

$=$ FISIM on assets + FISIM on liabilities + explicitly charged services, 
which can be derived from equations (11) and (12) using the relationships established in equations (13) and (14), after ignoring negative signs. We use equation (15) for our computations in our empirical study in Section 6.

Despite limitations and criticism against the user cost approach summarized in Section 4.1, which are equally applicable to FISIM also, FISIM has been slowly gaining acceptance among many countries. For instance, an OECD Task Force on Financial Services in National Accounts makes the following recommendation for SNA revision:

The reference rate approach towards measuring and allocating indirectlypriced financial services has recently gained significant ground in OECD countries' statistical practice. This convergence in approaches should be reflected in the SNA, although differences remain with regard to specificities of implementation such as the empirical choice of the reference rate.

(Schreyer and Stauffer, 2004)

After initial skepticism regarding FISIM, the present authors were more convinced about the practicality of FISIM after its implementation to Indian data. We provide details of FISIM computations for Indian data in Section 6. We also demonstrate in Section 6 that FISIM approach resolves both computations of GVA as well as its allocation to other sectors.

\subsection{Margin industry perspective}

The margin industry perspective by Triplett and Bosworth (2004) provide valuable insights into the issues of measurement of GVA of banks from the view points of economists working banking productivity and practitioners working national accounts. It strives to arrive at definitions of output and productivity in banking, which are 
satisfactory from economic definition of productivity and expert views of national accountants.

As already discussed in detail in Section 2, one of the basic problems associated with the SNA is the difficulty in proper treatment of interest earned from lending. Interest in national accounts is primarily a transfer or a receipt of property income involving owners of financial claim, and, is not regarded as a payment for a productive service. The concept of production used in the SNA requires some activity, or process, to take place involving labour and capital assets in which inputs are transformed into outputs and in which factor income are generated. Lending is not an activity of this kind. In the same spirit, deposits do not themselves provide productive inputs to banks in the SNA view.

This approach is sharply in contrast with the view of bank economists. For instance, a typical production function is a function is as follows:

Output in banking literature

$$
=\quad \sum \mathrm{r}_{\mathrm{m}} \mathrm{L}_{\mathrm{m}}+\sum\left(f_{g} S_{g}\right)_{\text {explicit }}+\sum\left(f_{g} S_{g}\right)_{\text {implicit }}
$$

where $L$ is the volume of loans with return $r, S$ is priced and unpriced services and $f$ is fee charged for explicit and implicit services.

In contrast, output in national accounts is defined as follows:

Output in national accounts

$$
=\left(\sum \mathrm{r}_{\mathrm{m}} \mathrm{L}_{\mathrm{m}}-\sum i_{j} D_{j}\right)+\sum\left(f_{g} S_{g}\right)_{\text {explicit }}
$$

where $D$ is the volume of deposits with interest cost $i$. In this definition, the difference between interest earned and interest paid is treated as "deemed transactions services" to depositors. "Deemed transaction services" include free services provided to depositors. 
Thus, unlike in manufacturing sector, there is total disagreement between the definition of output in banking sector as perceived by economists and as perceived by national accountants.

In order to reconcile the difference between these two views, Triplett and Bosworth (2004) proposed to consider banking as a margin industry. Their argument is embodied in the following quotation taken by them from an issue of Economist.

There is not much difference between financial firms and food suppliers. They buy and sell credit rather than cabbages, but they shift it from producer to consumer in much the same way, sometimes selling it as it is, other times canning it or pickling it or turning it into coleslaw; they sell it wholesale to other cabbage firms, or retail in the poshest emporiums and from the humblest market stalls... Nothing very special in that.

(Economist, April 7, 1990)

This view implies several intuitive production processes for the financial firm; they move credit, or the provision of finance, from place to place, or from primary producers to ultimate buyers, much like the wholesale-retail distribution system does for goods.

Analogy with retailing of agricultural produces, for instance, is easy to appreciate. Just as agricultural produces are cultivated in one part of the country (mainly rural areas) and distributed in other parts (mainly urban areas), bank credit is also produced and distributed. For instance, "Quarterly Statistics on Deposits and Credit of Scheduled Commercial Banks" reveals that, as at the end of Dec 2008, top 100 centres raised 69.2\% of deposits, while they used $78.6 \%$ of bank credit. This means that nearly $10 \%$ of credit was raised from outside the top 100 centres. Of course, reallocation of resources of economic units from savers to borrowers is a crucial function performed by banks. Triplett and Bosworth (2004) is just re-emphasizing this aspect from the point of view of margin industry. 
Even though the margin industry perspective throws some insights into the relevant issues in measurement of GVA of banks, as per our understanding, it does not provide a concrete way of computations, especially of allocation of GVA into different user sectors.

\section{A critical appraisal of existing methods and a search for missing components}

The current practices on measurement of output from banking sector provide reasonable coverage of its traditional functions of mobilization of deposits and dispensation of loans. However, as emphasized by Triplett and Bosworth (2004) and Schreyer and Stauffer (2004), there is substantial divergence between economic theory of banking and views of national accountants. Moreover, modern banking does far more complex functions as compared to its traditional operations of just collecting deposits and lending activities. For instance, had banks been played the simple traditional roles, the current sub-prime financial crisis would not have occurred, as it is a widely acknowledged fact that the crisis had originated in the US banking sector.

In order to view functions of modern banks, it is worth indicating important functions being done by banks, some of which are given below.

Risk management functions: Traditional deposit mobilization has certain elements of risk management, such as, safe custody of deposits and safe keeping facilities (locker facilities). Modern risk management tools, mostly availed by corporate houses, have made dramatic changes in traditional functions. Financial derivatives play the crucial role of risk sharing and risk transfer, which are mostly managed by commercial banks. Risk management tools sold by banks to corporate houses enable them to bundle and unbundle different components of risk. Banks also use securitization of their receivables, resulting again in bundling and unbundling of risk.

Liquidity transformation: As put forth by Diamond and Rajan (2005), one of the most important parts of banking is the transformation of liquidity structure from one set of 
customers (say, depositors) to another (say, creditors). This aspect has already been explained in detail in Section 3.

Both of these aspects have been dealt with in detail in an OECD document, which in fact suggested appropriate changes in SNA (Schreyer and Stauffer, 2004).

Social aspects of banking: Further, the recent financial crisis has brought forward the social aspects of banking, which has resulted in part-nationalisation of banks, a taboo in the developed world till the present financial crisis. In India, substantial efforts are being devoted for bringing of the under-privileged in the formal banking channel through financial inclusion. There have been specific directions to banks to open 'no-frills accounts', which opens up the world of banking to the poor. Based on the success of the concept of Grameen Banks of Bangladesh and the role of Self Help Groups (SHGs) in India, fruits of these efforts will be visible after a decade or so. Similar comments are applicable to the concept of priority sector advances, which have no parallels outside India. Thus, it is important to count contributions of these efforts towards national accounts.

Creation of broad money: One of the well accepted roles of banks in economic theory is their role in creation of broad money. In order to appreciate this point, consider an economy in which transactions are allowed only in hard currencies; that is, cheque transactions, credit / debit card, electronic fund transfers, etc. are not allowed. In this pure currency economy, no transactions are possible without actual currencies. Now introduce banks in this economy, in which 'chequable accounts' can be opened. In this economy, economic agents can undertake transactions through pure currency as well as through cheques. The economy as a whole gets benefit through additional money created through cheques, as the economic agents can undertake transactions much more smoothly, which is not measured in the current SNA FISIM approach. Alternative approaches, such as user cost of money or margin industry perspective, ignore the role of broad money creation by banks. 
Exact measurement of GVA from each of these value additions of banks require substantial debates among national accountants in collaboration with banking economists.

\section{Quantitative measures of banks' output}

In this section we present our computations based on FISIM methodology given in Section 4.2. We also compare these numbers with the published GVA for banks' by CSO. Efforts have also been made to allocate GVA from banks' to major sectors.

\subsection{GVA of banks: CSO computations}

Presently, CSO computes GVA from banks based on interest earnings, interest expenses, other income and operating costs using data in "Statistical Tables Relating to Banks in India", published by RBI. Exact formula followed by CSO is as follows:

GVA from banks

$=[$ Interest income - interest expenses $]+$ other income - operating costs

where operating costs exclude expenditure towards factors of production, viz., payment and provision to employees, depreciation on banks' property and directors' fees and allowances.

Table 1: GVA from banks - CSO computations

\begin{tabular}{|c|c|c|c|c|}
\hline \multirow{2}{*}{ Year } & \multicolumn{2}{|c|}{ GVA } & \multicolumn{2}{c|}{ Growth rate } \\
\cline { 2 - 5 } & $\begin{array}{c}\text { At current } \\
\text { prices }\end{array}$ & $\begin{array}{c}\text { At 1999-00 } \\
\text { prices }\end{array}$ & $\begin{array}{c}\text { At current } \\
\text { prices }\end{array}$ & $\begin{array}{c}\text { At 1999-00 } \\
\text { prices }\end{array}$ \\
\hline $1999-00$ & 40485 & 40485 & & \\
\hline $2000-01$ & 46966 & 45466 & 16.0 & 12.3 \\
\hline $2001-02$ & 55611 & 52562 & 18.4 & 15.6 \\
\hline $2002-03$ & 69222 & 63158 & 24.5 & 20.2 \\
\hline $2003-04$ & 83427 & 68772 & 20.5 & 8.9 \\
\hline $2004-05$ & 86283 & 79726 & 3.4 & 15.9 \\
\hline $2005-06$ & 91607 & 98510 & 6.2 & 23.6 \\
\hline $2006-07$ & 106841 & 118636 & 16.6 & 20.4 \\
\hline
\end{tabular}

Data source: National Accounts Statistics 2008. Figures for 2007-08 are not yet available. 
Equation (16) may be viewed as a way implementing the theoretical model developed in equation (10), Section 2. The net interest income is the same as $\left[I_{l}-I_{d}\right], F$ is the service charges, and $M$ is the intermediation cost. Thus, the present CSO approach has a theoretical basis, founded in a simple model of banking presented in Section 2.

Table 1 gives GVA as per CSO methodology for a few years.

One of the highlights of Table 1 is the constant price GVA for the year 2005-06, which is higher than the current price GVA. Higher value for constant price GVA seems to have come from the use of aggregate deposits. Computation of implicit price deflator and its comparison with FIS IM approach of the next section is given in Section 6.3.

\subsection{GVA of banks: FISIM computations}

FISIM computations presented here have been based on the model developed in equation (15), Section 4.2. We also borrow from a 2004 OECD document, which gives step-bystep approach for computing both current price and constant price GVA based on FISIM reference rate approach.

Table 2: GVA from banks - FISIM computations

\begin{tabular}{|c|r|r|r|r|}
\hline \multirow{2}{*}{ Year } & \multicolumn{2}{|c|}{ GVA } & \multicolumn{2}{c|}{ Growth rate } \\
\cline { 2 - 5 } & $\begin{array}{c}\text { At current } \\
\text { prices }\end{array}$ & $\begin{array}{c}\text { At 1999-00 } \\
\text { prices }\end{array}$ & $\begin{array}{c}\text { At current } \\
\text { prices }\end{array}$ & $\begin{array}{c}\text { At 1999-00 } \\
\text { prices }\end{array}$ \\
\hline $1999-00$ & 51293 & 51293 & & 7.4 \\
\hline $2000-01$ & 58211 & 55102 & 13.5 & 21.2 \\
\hline $2001-02$ & 65805 & 66765 & 13.0 & 17.2 \\
\hline $2002-03$ & 82762 & 78220 & 25.8 & 12.7 \\
\hline $2003-04$ & 98978 & 88132 & 19.6 & -0.1 \\
\hline $2004-05$ & 104458 & 88062 & 5.5 & 9.2 \\
\hline $2005-06$ & 117252 & 96153 & 12.2 & 25.4 \\
\hline $2006-07$ & 139973 & 107457 & 19.4 & 24.0 \\
\hline $2007-08$ & 173551 & 134699 & 24.0 \\
\hline
\end{tabular}

Note: Annual average WPI (with 1999-00 as the base) has been used for computing constant price GVA.

While the OECD document covers only loans and deposits, we cover all major assets and liabilities of banks, viz., deposits, borrowings, advances and investments. Interests 
expended and interests earned on these items are available in "Statistical Tables Relating to Banks in India", which has been used for computing effective interest rates.

The SNA93 reference rate has been computed on the basis recommendations and suggestions in OECD document and also Barman and Samanta (2004). FISIM reference rates have been thus computed as averages of effective interest rates of the four major items mentioned above. The reference rates so derived is then used for computing margin interest rates, which has been applied to the outstanding amounts to arrive at GVA from each of these five sectors. Total GVA based on FISIM methodology is then computed. While OECD document does not cover other income coming from direct services, this has been added to FISIM based GVA to arrive at total GVA of the banking sector.

Quick comparison between GVA at current prices reported in the two tables reveal that FISIM based GVA is on higher side as compared to the existing CSO methodology.

\subsection{Implicit price deflator}

Table 3 below presents implicit price deflator as per CSO approach, FISIM approach and the actual annual average WPI; for comparison purposes, WPI has been deflated to have base as 1999-00.

Table 3: Implicit price deflator - a comparison

\begin{tabular}{|c|c|c|c|}
\hline \multirow{2}{*}{ Year } & \multicolumn{3}{|c|}{ Implicit price deflator } \\
\cline { 2 - 4 } & As per CSO approach & As per FISIM approach & Average WPI \\
\hline $1999-00$ & 100.0 & 100 & 100 \\
\hline $2000-01$ & 103.3 & 106 & 107 \\
\hline $2001-02$ & 105.8 & 99 & 111 \\
\hline $2002-03$ & 109.6 & 106 & 115 \\
\hline $2003-04$ & 121.3 & 112 & 121 \\
\hline $2004-05$ & 108.2 & 119 & 129 \\
\hline $2005-06$ & 93.0 & 122 & 135 \\
\hline $2006-07$ & 90.1 & 130 & 142 \\
\hline $2007-08$ & - & 129 & 149 \\
\hline
\end{tabular}

Notes: Annual average WPI has been deflated to have base as 1999-00 for comparison purpose, which has also been used as deflator for computation constant price computations in Table 2. 
Table 3 reveals that the price deflator based on FISIM approach is more or less in alignment with the WPI, while CSO approach yields price deflator with wide variability, especially since 2005-06. This is not very surprising, as CSO computes constant price GVA from growth rates of aggregate deposits applied to the base year, while FISIM computes all numbers in a consistent manner from the same set of original data sources.

\subsection{Sector-wise allocations - some suggestions}

On the basis of FISIM GVA values for deposits, advances and investments, it is possible to allocate it to different user sectors, such as government, households and foreign sectors. Such allocations may be done using data published by RBI within BSR System of returns. In particular, allocation of deposits is possible on the basis of ownership of deposits; allocation of advances is possible on the basis of similar classification and allocation of investments is possible on the basis of classification of investments. One way possible way of doing this allocation is to apply shares of different sectors on the total FISIM computed. For instance, in the case of deposits, one may compute share of sectors as per ownership data and allocate the total FISIM as per this data. Table 3 provides an illustration of these computations for deposits.

Table 3: Allocation of GVA of deposits for 2008

\begin{tabular}{|l|c|c|c|}
\hline Sector & Amount & Share in \% & GVA allocated \\
\hline Government & 390673 & 14.5 & 3997 \\
\hline $\begin{array}{l}\text { Private non- } \\
\text { financial corporate }\end{array}$ & 303482 & 11.2 & 3105 \\
\hline Financial & 282465 & 10.5 & 2890 \\
\hline Households & 1549716 & 57.4 & 15855 \\
\hline Foreign & 173565 & 6.4 & 1776 \\
\hline Total & 2699901 & 100.0 & 27623 \\
\hline
\end{tabular}

Notes: Total GVA is computed using FISIM methodology and then allocated to different sectors as per share obtained from ownership data for the year 2006-07. Similar methodology can be followed for advances and investments.

Thus, as per the analysis presented in this section, most issues faced in national accounts for banking sector can be resolved using FISIM methodology using the concept of reference rates. 


\section{Concluding re marks}

The paper attempts to present current status of measurement of output from banking sector. As is evident from highly diverging views, measurement of GVA both at current prices and at constant prices is a challenging task and, as illustrated in Section 6, we present a methodology compatible with OECD and also resolving some of the issues using FISIM methodology in the Indian context.

However, measurement of GVA as visualized in SNA93 largely pertains to traditional intermediation activities of deposit taking and lending, which in the process, ignores important banking aspects of risk management, soft money creation through the money multiplier and liquidity management; this has been detailed in Section 5.

Current methods also completely ignores important role being played by banks as agents of social changes in the form of providing credit needs of the under-privileged; as demonstrated by the current financial crisis, this aspect of modern banking cannot be ignored.

While we do not have concrete suggestions in improving measurement of 'unaccounted' aspects of banking, it is important to bring them to the attention of public policy makers, which the present paper hope to achieve.

\section{References}

Barnett, W. (1980). Economic monetary aggregates. Journal of Econometrics, 11-48, Volume 14.

Barman, R.B. and G.P.Samanta (2004). Banking Services Price Index: an exploratory analysis for India. IFC Bulletin, Bank for International Settlement.

Central Statistical Organisation(1989), National Accounts Statistics: Sources and Methods ,

Collins R. and Sciadas G. (1993). Measuring the output of banks. Voorburg Group Conference, Oslo, available at www4.statcan.ca/English/voorburg. 
Diamond, Douglas and Raghuram Rajan (2005). Liquidity shortages and banking crises. Journal of Finance, 615-647, Volume LX, No.2.

Donovan, D.J. (1978). Modeling the demand for liquid assets: application to Canada. International Monetary Fund Staff Papers, 676-704, Volume 25.

Fixler, Dennis (1993). Measuring financial service output and prices in commercial banking. Applied Economics, 983-993, Volume 25.

Fixler, Dennis and Kimberly Zieschang (1992). User costs, shadow prices, and the real output of banks. In Griliches, Z. (editor), Output measurement in the service sector, University of Chicago Press, 219-243.

Fixler, Dennis and Kimberley Zieschang (1999). The productivity of the banking sector: integrating financial and production approaches to measuring financial service output. Canadian Journal of Economics, 547-569, Volume 32, No. 2.

Hancock, Diana (1985). The financial firm: production with monetary and nonmonetary goods. Journal of Political Economy, 859-880, Volume 95, No. 5.

OECD (1998). FISIM. Notes by OECD secretariat prepared for Joint OECD/ESCAP Meeting on National Accounts. Bangkok, May 1998.

Samanta, G.P. and R.B.Barman (2004). Banking services price index: an exploratory analysis for India. IFC Bulletin, No. 19, Bank for International Settlement.

Sciadas, G. (1994). The measurement of banking output and the treatment of interest in the system of national accounts. Ph.D. thesis, McGill University, Montreal.

Schreyer, Paul and Philippe Stauffer (2004). SNA revision process: Provisional recommendations on the measurement of the production of (non-insurance) financial corporations. OECD.

Triplett, Jack E. and Barry P. Bosworth (2004). Productivity in the U.S. Services Sector, Chapter 7. Brookings Institution Press, Washington DC.

United Nations (1993). System of National Accounts.

Wang, J. Christina, Susanto Basu and J.G.Fernald (2004). A general-equilibrium assetpricing approach to the measurement of nominal and real bank output. Prepared for CRIW conference on price index concepts \& measurement, Vancouver. 